\title{
PENGARUH PENAMBAHAN MALTODEKSTRIN TERHADAP KARAKTERISTIK FISIKOKIMIA BUBUK TOMAT HASIL PENGERINGAN PEMBUSAAN (FOAM MAT DRYING)
}

\author{
Effect of Maltodextrin Addition on The Physicochemical Properties of Tomato \\ Powder Processed by Foam Mat Drying
}

\author{
Asri Widyasanti*, Nur Alifa Septianti, dan Sarifah Nurjanah \\ Program Studi Teknik Pertanian, Fakultas Teknologi Industri Pertanian, Universitas \\ Padjadjaran, Jl. Bandung Sumedang Km 21, Jatinangor, Sumedang, 40600 \\ *Alamat Korespondensi: asri.widyasanti@unpad.ac.id
}

\begin{abstract}
ABSTRAK
Tomat termasuk komoditas tanaman yang banyak dijumpai di Indonesia, namun memiliki nilai ekonomi yang rendah dan mudah rusak. Salah satu usaha yang dapat dilakukan untuk mengatasi hal tersebut adalah dengan mengolah tomat menjadi berbagai produk olahan salah satunya adalah pembuatan bubuk tomat. Pembuatan bubuk suatu bahan dapat dilakukan dengan metode pengeringan pembusaan. Penelitian bertujuan untuk mengetahui pengaruh penambahan maltodekstrin sebagai bahan pengisi terhadap karakteristik fisikokimia bubuk tomat yang dihasilkan. Metode yang digunakan dalam penelitian ini adalah eksperimental laboratorium dengan analisis deskriptif. Perlakuan yang dicoba adalah penambahan maltodekstrin $(10 \%, 15 \%$ dan $20 \% \mathrm{~b} / \mathrm{b})$, dengan tiga kali ulangan. Parameter yang diamati meliputi: rendemen, warna, laju pengeringan, dan karakteristik fisikokimia bubuk tomat yang meliputi warna, kadar air, kadar abu, kelarutan, indeks penyerapan air, bulk density, foam density, kadar vitamin C, dan higroskopisitas. Hasil penelitian menunjukkan rata-rata kadar air awal campuran jus dan pulp tomat hasil proses mixing adalah $82,68 \%$ (bb) hingga 94,9\% (bb). Nilai kadar air bubuk tomat berkisar antara $5,86 \%$ (bb) hingga 15,28\% (bb). Pada penelitian ini hasil terbaik terdapat pada bubuk tomat dengan perlakuan penambahan maltodekstrin 20\% dengan hasil rendemen 15,29\%; kadar air 5,86\%; kadar abu 6,24\%; foam density $0,57 \mathrm{~g} / \mathrm{cm}^{3}$; bulk density $0,77 \mathrm{~g} / \mathrm{cm}^{3}$; kelarutan 95,23\%; indeks penyerapan air 12,96\%; tingkat higroskopisitas 11,36\%; kadar vitamin C 75,49 mg/100g. Karakteristik warna bubuk tomat pada perlakuan penambahan maltodekstrin maupun kontrol menghasilkan warna kromatis merah.
\end{abstract}

Kata kunci: bubuk tomat, maltodekstrin, pengeringan pembusaan, tomat

\begin{abstract}
Tomato is one of plant commodities that easy to find in Indonesia, but it is easily damaged and has a low economic price. One of the alternative to solve the problem was performed by processing the fresh tomato into tomato powder. Tomato powder can made by foam mat drying method. The purpose of this study was to determine the effect of maltodextrin addition as a filler material on physicochemical properties of tomato powder that made by foam mat drying. This study conducted with laboratory experimental method with descriptive analysis. There were three repetitions that consisted of 3 treatments based on the maltodextrin addition $(10 \%, 15 \%$ and $20 \% \mathrm{w} / \mathrm{w})$. The observed parameters were total yield value, colour, drying rate, and physicochemical properties such as colour, moisture content, ash content, solubility, water absorption index, bulk density, foam density, vitamin $C$ content, and hygroscopicity. The results showed that the average moisture content of tomato juice and pulp from mixing process was $82.68 \%(\mathrm{bb})$ to $94.9 \%(\mathrm{bb})$. The value of tomato powder water content ranges from $5.86 \%$ (bb) to $15.28 \%(b b)$. In this study, the best results were found in tomato powder with $20 \%$ maltodextrin addition treatment with total yield of $15.29 \% ; 5.86 \%$ moisture content; $6.24 \%$ ash content; foam density $0.57 \mathrm{~g} / \mathrm{cm}^{3} ; \mathrm{bulk}$ density $0.77 \mathrm{~g} / \mathrm{cm}^{3} ; 95.23 \%$ solubility; water absorption index $12.62 \%$; hygroscopicity $11.36 \%$; vitamin C content $75.49 \mathrm{mg} / 100 \mathrm{~g}$. All of maltodextrin additions and control treatments with and without maltodextrin were resulting red chromatic colour characteristic.
\end{abstract}

Keywords: foam mat drying, maltodextrin, tomato, tomato powder 


\section{PENDAHULUAN}

Tomat mengandung komponen nutrisi terutama kaya akan vitamin dan mineral. Dalam satu buah tomat segar ukuran sedang (100 gram) mengandung sekitar 24 kalori, 34 mg vitamin C, 1500 SI vitamin A, $60 \mathrm{mg}$ tiamin (vitamin B), zat besi, kalsium dan lain-lain (Departemen Kesehatan Republik Indonesia, 1995).Vitamin A dan C merupakan zat gizi yang jumlahnya cukup dominan dalam buah tomat.

Permasalahan yang sering terjadi di Indonesia adalah pada saat panen raya, harga buah tomat sangat rendah. Hal ini berdampak pada keadaan ekonomi para petani tomat. Disisi lain, buah tomat mudah mengalami kerusakan jika tidak disimpan pada kondisi yang baik. Kandungan air dan komponen pektin yang tinggi pada buah tomat, menyebabkan komoditas ini mudah mengalami kerusakan fisik, kimia maupun mikrobiologis. Salah satu alternatif yang dapat dilakukan untuk mencegah kerusakan buah tomat yaitu mengolahnya menjadi berbagai produk olahan.

Nurcholis dkk. (2010) menyatakan, pengolahan tomat ditujukan untuk meningkatkan keanekaragaman produk, nilai guna maupun nilai ekonomi serta memperpanjang umur simpan. Buah tomat dapat digunakan dalam pembuatan aneka jenis makanan tradisional, minuman serta untuk pemenuhan gizi masyarakat.
Beberapa jenis produk olahan berbasis tomat diantaranya selai, permen jelly, jelly drink, tomakur (tomat rasa kurma), saus, pasta, sari buah, manisan kering maupun produk dalam bentuk bubuk. Bentuk bubuk merupakan produk yang lebih awet, ringan, volumenya lebih kecil sehingga dapat mempermudah dalam pengemasan dan pengangkutan.

Metode pengeringan yang cocok untuk tomat adalah foam mat drying karena tomat termasuk ke dalam salah satu bahan yang sulit dikeringkan. Dalam foam mat dyring, bahan berbentuk cair dirubah terlebih dahulu menjadi busa dengan cara bahan cair ditambahkan zat pembusa (foaming agent) kemudian dilakukan pengocokan. Pengeringan dilakukan dengan menggunakan udara panas pada tekanan atmosfer, dan bahan yang dikeringkan dalam bentuk lembaran tipis. Pengeringan pembusaan (foam mat dying) dapat memperluas permukaan bahan sehingga dapat mempercepat proses penguapan air (Rajkumar et al., 2006). Pada metode pengeringan ini yang berpengaruh adalah suhu pengeringan, jumlah bahan pengisi serta jumlah foaming agent (bahan pembusa). Metode foam-mat drying membutuhkan zat pembuih yang berfungsi sebagai pendorong pembentukan busa dan penambahan bahan pengisi yang dapat mempercepat proses pengeringan, meningkatkan total padatan, mencegah 
kerusakan zat gizi akibat panas selama pengeringan, melapisi komponen flavour dan memperbesar volume (Mulyani dkk., 2014). Namun perlu diketahui pula apakah perbedaan penambahan maltodekstrin sebagai bahan pengisi yang digunakan memberikan pengaruh pada karakteristik fisikokimia bubuk tomat hasil pengeringan pembusaan, sehingga pada penelitian ini akan diamati pengaruh penambahan maltodekstrin sebagai bahan pengisi terhadap karakteristik fisikokimia bubuk tomat hasil pengeringan pembusaan. Penelitian bertujuan untuk mengetahui pengaruh penambahan maltodekstrin sebagai bahan pengisi terhadap karakteristik fisikokimia bubuk tomat yang dihasilkan.

\section{METODE PENELITIAN}

Bahan-bahan yang digunakan pada penelitian ini, yaitu buah tomat apel segar (berasal dari Ciwidey, Bandung, Jawa Barat), putih telur (ayam negeri), air bersih, dan maltodekstrin sebagai bahan pengental (food grade dari Kimia Mart), kertas saring Whatman 42, kertas saring teknis, aquades, larutan $I_{2} \quad 0,01 \quad N$, larutan amylum $1 \%$. Metode penelitian yang digunakan adalah metode eksperimental laboratorium dengan menggunakan analisis deskriptif.

\section{Pembuatan Bubuk Tomat}

Buah tomat apel segar yang dipanen pada umur 75 hari sebanyak $1000 \mathrm{~g}$, dengan warna dominan merah, dicuci hingga bersih menggunakan air mengalir. Buah tomat dipotong dan bijinya dipisahkan dari daging tomat. Daging buah tomat di blender selama 3 menit, diperoleh jus dan pulp tomat. Jus dan pulp tomat dicampurkan dengan maltodekstrin sesuai dengan perlakuan yaitu $(10 \%, 15 \%$, dan $20 \% \mathrm{~b} / \mathrm{b})$ kemudian dikocok menggunakan mixer selama 2 menit. Putih telur 5\% b/b dikocok menggunakan mixer dengan kecepatan 3 selama 4,5 menit sehingga terbentuk busa. Jus dan pulp tomat yang sudah dikocok dengan maltodekstrin dicampurkan dengan busa putih telur sesuai perlakuan kemudian dikocok menggunakan mixer selama 10 menit pada kecepatan 3. Campuran dituangkan ke dalam loyang alumunium yang sudah dilapisi dengan alas plastik tahan panas dengan ketebalan $3 \mathrm{~mm}$. Pengeringan dilakukan dengan menggunakan oven konveksi selama 8-10 jam dengan suhu $60^{\circ} \mathrm{C}$. Lembaran kering tomat kemudian ditimbang menggunakan timbangan analitik. Lembaran kering tomat dihancurkan menggunakan grinder selama 2 menit sehingga diperoleh bubuk tomat dan kemudian ditimbang kembali menggunakan timbangan analitik. Bubuk tomat kemudian diayak dengan Ayakan Tyler berukuran 60 mesh agar memiliki ukuran yang seragam. Bubuk tomat yang lolos kemudian ditimbang menggunakan timbangan analitik. 


\section{Parameter Pengamatan}

Rendemen total bubuk tomat dihitung dengan persamaan berikut:

Rendemen total $(\%)=\frac{M_{h}}{M_{a}} \times 100 \%$

Keterangan:

$\mathrm{Mh}=$ Massa bubuk tomat $(\mathrm{g})$

$\mathrm{Ma}=$ Massa tomat segar $(\mathrm{g})$

Laju pengeringan ditentukan dengan mengukur kadar air bahan untuk interval waktu $0,2,4,6,8,10,20,40,60,120,180$, 240, 300, 360, 420, 480, 540, 600 menit Perhitungan laju pengeringan menggunakan persamaan berikut:

$$
\mathrm{LP}=\frac{\mathrm{m}_{\mathrm{o}}-\mathrm{m}_{\mathrm{t}}}{\mathrm{t}_{\text {kumulatif }}}
$$

Keterangan:

LP = laju pengeringan

$\mathrm{m}_{0} \quad=$ massa bahan awal $(\mathrm{g})$

$\mathrm{m}_{\mathrm{t}} \quad=$ massa jus tomat kering menit ke$\mathrm{t}(\mathrm{g})$

$t_{\text {kumulatif }}=$ waktu kumulatif (menit)

Penentuan warna bubuk tomat dilakukan dengan pengolahan citra dengan menggunakan alat analisa warna spektrofotometer CM-5 dalam memperoleh nilai $L^{*}, a^{*}, b^{*}$, chroma, dan Hue.

Prinsip pengukuran kadar air dilakukan dengan metode oven, yaitu dengan cara mengeluarkan air dari bahan dengan bantuan energi panas dan didasarkan atas massa bahan yang hilang. Kadar air yang diukur adalah kadar air awal, kadar air setelah pengeringan, dan kadar air bubuk tomat. Sampel masing-masing sebesar $5 \mathrm{~g}$, dioven dengan suhu $105^{\circ} \mathrm{C}$ hingga diperoleh berat konstan. Perhitungan kadar air dengan menggunakan persamaan berikut:

$$
\text { K.A. }(\% b b)=\frac{B_{b}-\left(B_{c}-B_{a}\right)}{B_{b}} \times 100 \%
$$

Keterangan:

K.A. $=$ kadar air

$\mathrm{B}_{\mathrm{a}}=$ massa cawan kering $(\mathrm{g})$

$\mathrm{B}_{\mathrm{b}}=$ massa sampel awal dan cawan $(\mathrm{g})$

$\mathrm{B}_{\mathrm{c}}=$ massa cawan dan sampel kering konstan $(\mathrm{g})$

Penentuan abu total bertujuan untuk menentukan baik tidaknya suatu proses pengolahan, untuk mengetahui jenis bahan yang digunakan, dan sebagai parameter nilai gizi bahan makanan. Penentuan kadar abu dilakukan dengan memanaskan bahan sebanyak $5 \mathrm{~g}$ pada tanur dengan suhu $600^{\circ} \mathrm{C}$ selama 3 jam. Bahan lain selain mineral akan terbakar dan menguap. Bobot yang tertinggal setelah pemanasan adalah abu atau mineral. Perhitungan kadar abu menggunakan persamaan berikut:

$$
\text { Kadar abu }(\%)=\frac{B_{c}-B_{a}}{B_{b}-B_{a}} \times 100 \%
$$

Keterangan:

$\mathrm{B}_{\mathrm{a}}=$ massa cawan kering $(\mathrm{g})$

$\mathrm{B}_{\mathrm{b}}=$ massa sampel awal dan cawan $(\mathrm{g})$

$\mathrm{B}_{\mathrm{c}}=$ massa cawan dan sampel kering yang sudah konstan $(\mathrm{g})$

Foam (campuran jus tomat, maltodekstrin, dan putih telur yang sudah dimixing) dituangkan sebanyak $50 \mathrm{ml}$ ke dalam gelas ukur $50 \mathrm{ml}$. Perhitungan foam density menggunakan persamaan berikut: 


$$
\text { Foam density }=\frac{\text { berat } \text { foam }(\mathrm{g})}{\text { volume } \text { foam }\left(\mathrm{cm}^{3}\right)}
$$

Sampel bubuk tomat sebanyak $10 \mathrm{~g}$ dimasukan ke dalam gelas ukur $100 \mathrm{~mL}$. Bagian bawah gelas ukur ditepuk-tepuk beberapa kali hingga diperoleh berat konstan. Perhitungan bulk density menggunakan persamaan berikut:

$$
\rho_{\mathrm{b}}=\frac{\mathrm{m}_{\mathrm{s}}}{\mathrm{v}_{\mathrm{s}}}
$$

\section{Keterangan:}

$\rho_{\mathrm{b}}=$ bulk density bubuk tomat $\left(\mathrm{g} / \mathrm{cm}^{3}\right)$

$\mathrm{m}_{\mathrm{s}}=$ massa sampel bubuk $(\mathrm{g})$

$\mathrm{v}_{\mathrm{s}}=$ volume bubuk $\left(\mathrm{cm}^{3}\right)$

Pengukuran kelarutan metode gravimetri dilakukan dengan mengeringkan kertas saring Whatman No. 42 dalam oven dengan suhu $105^{\circ} \mathrm{C}$ selama 30 menit, kemudian ditimbang beratnya. Sampel bubuk tomat sebanyak 3,5 g (berat awal) ke dalam $100 \mathrm{~mL}$ air aquades kemudian disaring dengan kertas saring Whatman No. 42 menggunakan corong Buchner dengan sistem vakum. Selanjutnya kertas saring tersebut kemudian dioven dengan suhu $105^{\circ} \mathrm{C}$ selama 3 jam, kemudian didinginkan di desikator dan ditimbang. Kelarutan dihitung menggunakan persamaan berikut:

$$
\text { Kelarutan }=\frac{\text { berat awal-berat akhir }}{\text { berat awal }} \times 100 \%
$$

\section{Keterangan:}

Berat akhir merupakan selisih dari berat kertas saring Whatman No. 42 setelah dilakukan penyaringan (g) dengan berat kertas saring Whatman No. 42 sebelum dilakukan penyaringan $(\mathrm{g})$

\section{Indeks Penyerapan Air}

Pengukuran indeks penyerapan air dilakukan dengan mencampurkan $1 \mathrm{~g}$ bubuk tomat dengan $10 \mathrm{ml}$ aquades, kemudian disentrifugasi dengan kecepatan $2000 \mathrm{rpm}$ selama 15 menit. Selanjutnya pellet dipanaskan menggunakan oven selama 25 menit pada suhu $50^{\circ} \mathrm{C}$. Perhitungan indeks penyerapan air dengan menggunakan persamaan berikut:

$$
\text { IPA }=\frac{\text { berat awal }(A)}{\text { berat air yang terserap (B) }}
$$

Keterangan:

IPA = indeks penyerapan air

Berdasarkan GEA Niro Research Laboratory (2005), bahan dengan tingkat higroskopisitas $<10 \%$ tergolong ke dalam bahan yang tidak higroskopis, 10,1\%-15\% tergolong ke dalam bahan yang sedikit higroskopis, 15,1\%-20\% tergolong ke dalam bahan yang higroskopis, 20,1\%-25\% tegolong ke dalam bahan yang sangat higroskopis, dan $>25 \%$ bahan tergolong sangat higroskopis sekali. Perhitungan higroskopisitas menggunakan persamaan berikut ini:

$$
\mathrm{H}(\%)=\frac{(\% \mathrm{Wi}+\% \mathrm{Fw}) \times 100}{100+\% \mathrm{Wi}}
$$

Keterangan:

$\mathrm{H}=$ Higroskopisitas

FW $(\%)=$ kadar air awal bahan

Wi $(\%)=\frac{\text { Berat air yang terserap }}{\text { Berat bahan }} \times 100 \%$ 
Pengukuran kadar vitamin $\mathrm{C}$ dilakukan dengan cara titrasi iodimetri. Perhitungan kadar vitamin C menggunakan persamaan berikut ini:

$$
\mathrm{KVC}=\frac{\mathbf{v I}_{2} \times \mathrm{Fpx} \frac{\mathrm{NI}_{2}}{0,01 \mathrm{~N}} \mathbf{x}, \mathbf{8 8}}{\mathbf{m}}(12)
$$

Keterangan:

$\mathrm{KVC}=$ kadar vitamin $\mathrm{C}$

$\mathrm{vI}_{2}=$ volume larutan $\mathrm{I}_{2}$ titrasi

$\mathrm{Fp}=$ faktor pengenceran

$\mathrm{NI}_{2}=$ normalitas $\mathrm{I}_{2}$ hasil pembuatan

$\mathrm{m}=$ massa sampel

\section{HASIL DAN PEMBAHASAN}

\section{Rendemen Total}

Rendemen total merupakan perbandingan massa bubuk tomat yang lolos mesh 60 dengan massa bahan baku (tomat segar) yang digunakan. Semakin besar nilai rendemen total tiap perlakuan menunjukkan semakin efektif dan efisien proses pembuatan bubuk tomat. Rata-rata rendemen total pembuatan bubuk tomat tersaji pada Gambar 1.

Berdasarkan Gambar 1, rata-rata nilai rendemen terbesar adalah pada perlakuan penambahan maltodekstrin $20 \%$ dan putih telur 5\% (perlakuan C) dengan hasil rendemen yaitu 15,29\%. Penambahan maltodekstrin tertinggi menghasilkan rendemen bubuk tomat apel yang tinggi dan sebaliknya penambahan maltodekstrin terendah menghasilkan rendemen rendah. Maltodekstrin memiliki daya ikat yang besar terhadap air (Hayati dkk., 2015). Semakin banyak maltodekstrin yang ditambahkan maka semakin tinggi rendemen totalnya, hal ini diduga karena semakin banyak air yang terikat oleh maltodekstrin.

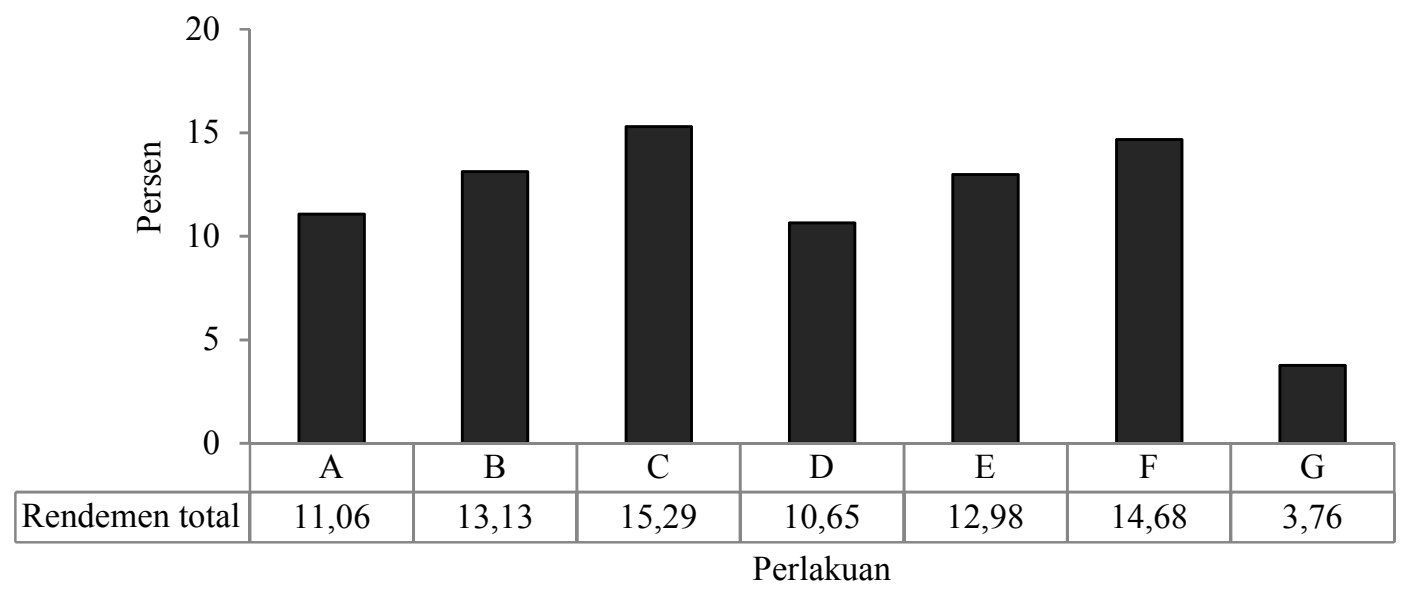

Gambar 1. Rendemen total pembuatan bubuk tomat. Keterangan: $A=$ maltodekstrin $10 \%$, putih telur 5\%; B = maltodekstrin $15 \%$ putih telur $5 \% ; \mathrm{C}=$ maltodekstrin $20 \%$, putih telur $5 \% ; \mathrm{D}=$ maltodekstrin $10 \% ; \mathrm{E}=$ maltodekstrin $15 \% ; \mathrm{F}=$ maltodekstrin $20 \%$; dan $\mathrm{G}=$ putih telur $5 \%$. 
Pada perlakuan penambahan maltodekstrin dan putih telur (perlakuan A, $\mathrm{B}$, dan $\mathrm{C}$ ), nilai rendemen total cenderung lebih besar dibanding dengan perlakuan kontrol maltodekstrin maupun kontrol putih telur. Adanya putih telur diduga dapat menambah rendemen total bahan yang dikeringkan. Penambahan busa putih telur dapat meningkatkan total padatan pada bahan (Kamsiati, 2004). Putih telur mengandung 86,7\% air, sehingga sisanya adalah padatan Peningkatan total padatan dapat meningkatkan berat produk akhir yang berakibat pada naiknya rendemen (Kamsiati, 2004).
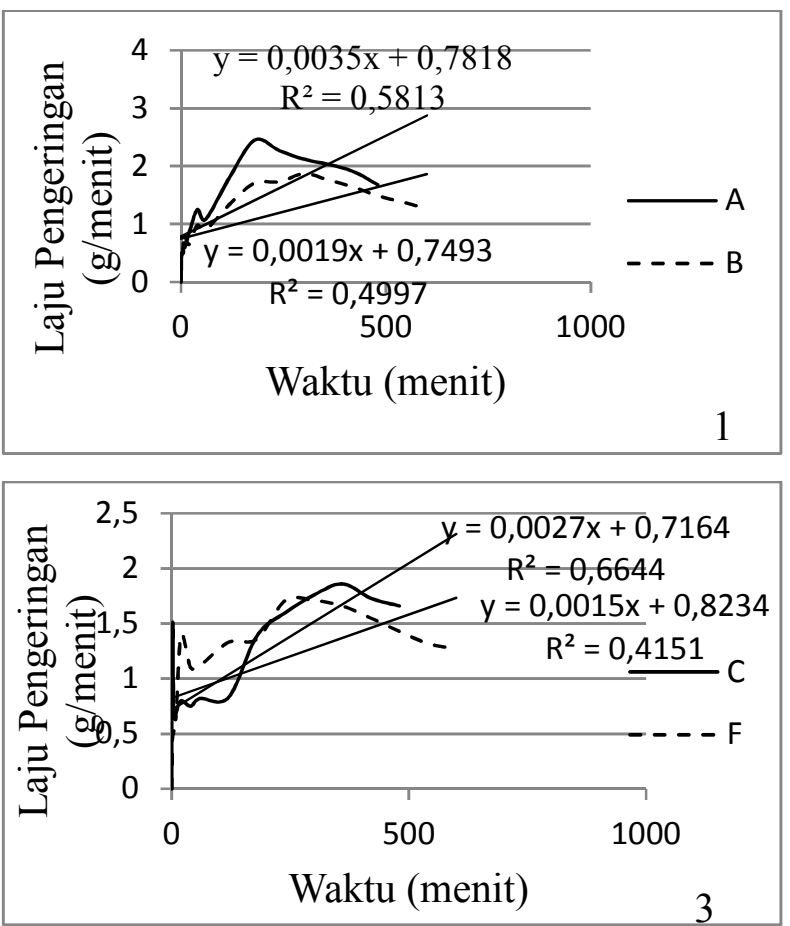

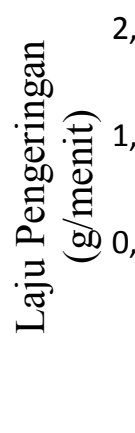

\section{Laju Pengeringan}

Laju pengeringan dapat dinyatakan sebagai jumlah massa air yang teruapkan dari dalam bahan persatuan waktu, sehingga dapat meggambarkan seberapa cepat proses pengeringan berlangsung. Pengeringan pembusaan (foam mat drying) dapat memperluas permukaan bahan sehingga dapat mempercepat proses penguapan air (Rajkumar et al., 2006). Pada metode pengeringan ini yang berpengaruh adalah suhu pengeringan, jumlah bahan pengisi serta jumlah foaming agent (bahan pembusa). Rata-rata laju pengeringan dapat dilihat pada Gambar 2.

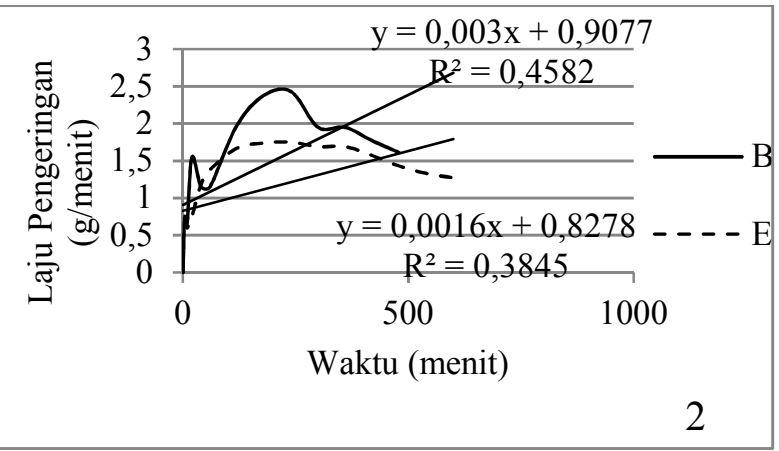

Gambar 2. Laju Pengeringan Perlakuan. 1. Penambahan Maltodekstrin 10\%, 2. Penambahan Maltodekstrin 15\%, 3. Penambahan Maltodekstrin 20\%, dan 4. Penambahan Putih Telur 5\%. Keterangan: $\_=$perlakuan dengan pengeringan pembusaan; -..... = perlakuan tanpa pengeringan pembusaan; $\mathrm{A}=$ maltodekstrin $10 \%$, putih telur $5 \%$; $\mathrm{B}=$ maltodekstrin $15 \%$, putih telur $5 \%$; $\mathrm{C}=$ maltodekstrin $20 \%$, putih telur $5 \%$; D = maltodekstrin $10 \%$; $\mathrm{E}=$ maltodekstrin $15 \% ; \mathrm{F}=$ maltodekstrin $20 \%$ dan $\mathrm{G}=$ putih telur $5 \%$. 
Semakin banyak maltodekstrin yang ditambahkan diduga akan menurunkan laju pengeringan. Penambahan maltodekstrin diduga dapat menurunkan kadar air sehingga dapat menurunkan laju pengeringan. Penambahan maltodekstrin juga dapat meningkatkan total padatan bahan. Semakin besar total padatan dalam bahan yang dikeringkan, diduga akan menurunkan jumlah air yang harus dievaporasi, sehingga menurunkan itu laju pengeringan. Laju pengeringan perlakuan dengan pengeringan pembusaan lebih cepat dibandingkan dengan laju pengeringan perlakuan tanpa pengeringan pembusaan. Diduga putih telur akan membentuk busa yang dapat memperluas permukaan sehingga kontak udara pengering dengan bahan yang dikeringkan lebih besar maka air yang diuapkan lebih banyak. Maltodekstrin diduga dapat mempertahankan gelembung yang terbentuk dari putih telur, sehingga luas kontak dengan media pengering dijaga tetap luas, sampai pengeringan selesai (Djaeni dkk., 2016). Laju pengeringan terendah terjadi pada perlakuan kontrol dengan penambahan maltodekstrin 20\%. Hal ini diduga karena total padatan pada bahan yang dikeringkan bertambah sehingga jumlah air yang dievaporasi akan berkurang. Proses pengeringan dengan menggunakan oven dapat mengurangi waktu pengeringan dan dapat menghasilkan bubuk tomat dengan kualitas baik. Suhu pengeringan $60^{\circ} \mathrm{C}$ dianggap paling optimal dalam pembuatan bubuk tomat dengan kualitas fisik dan sensoris bubuk tomat terbaik.

\section{Warna}

Warna merupakan parameter yang berpengaruh langsung terhadap sensori manusia. Pada penelitian ini dilakukan pengujian warna masing-masing sampel bubuk tomat, lembaran kering tomat, maupun warna jus dan pulp tomat termasuk perlakuan kontrol. Hasil pengujian warna $\left(\mathrm{L}^{*}, \mathrm{a}^{*}, \mathrm{~b}^{*}\right)$, nilai kroma dan Hue terdapat pada Tabel 1 .

Notasi $L^{*}$ menyatakan kecerahan pada bubuk tomat. Nilai L* berkisar antara 0 (hitam) hingga 100 (putih). Berdasarkan Tabel 2., nilai $L^{*}$ dari bubuk tomat menunjukkan nilai yang semakin besar pada penambahan maltodekstrin. Nilai L* dari bubuk tomat semua perlakuan lebih dari 50, sehingga ekstrak tersebut digolongkan agak terang. Konsentrasi maltodekstrin tinggi meningkatkan perlindungan warna bubuk. Konsentrasi maltodekstrin rendah menyebabkan rendahnya pelapisan terhadap warna bubuk sehingga warna bubuk menjadi coklat akibat perlakuan suhu pengeringan tinggi (Paramita dkk., 2014). 
p-ISSN: 1410-0029; e-ISSN2549-6786

Agrin Vol. 22, No. 1, April 2018

Tabel 1. Data pengujian warna

\begin{tabular}{ccccccc}
\hline \multirow{2}{*}{ Perlakuan } & \multicolumn{9}{c}{ Parameter Warna } & Warna \\
\cline { 2 - 7 } & $\mathrm{L}^{*}$ & $\mathrm{a}^{*}$ & $\mathrm{~b}^{*}$ & $\mathrm{c}$ & $\mathrm{H}$ & \\
\hline $\mathrm{A}$ & 68,20 & 19,44 & 23,53 & 30,71 & 50,65 & Red \\
$\mathrm{B}$ & 72,94 & 17,31 & 20,00 & 26,61 & 49,62 & Red \\
C & 73,79 & 17,53 & 19,00 & 26,00 & 47,76 & Red \\
D & 59,27 & 25,65 & 25,48 & 36,19 & 44,85 & Red \\
E & 62,31 & 24,10 & 25,57 & 35,23 & 46,65 & Red \\
F & 67,07 & 21,57 & 23,97 & 32,38 & 48,23 & Red \\
G & 50,96 & 25,73 & 26,40 & 36,87 & 45,74 & Red \\
Jus dan pulp tomat & 39,06 & 31,57 & 23,32 & 39,25 & 36,45 & Red \\
Lembaran kering tomat & 37,27 & 33,34 & 23,39 & 40,82 & 35,65 & Red \\
\hline
\end{tabular}

Keterangan: $\mathrm{A}=$ maltodekstrin $10 \%$, putih telur $5 \%$; $\mathrm{B}=$ maltodekstrin $15 \%$, putih telur $5 \%$; $\mathrm{C}=$ maltodekstrin $20 \%$, putih telur $5 \% ; \mathrm{D}=$ maltodekstrin $10 \% ; \mathrm{E}=$ maltodekstrin $15 \% ; \mathrm{F}=$ maltodekstrin $20 \%$ dan $\mathrm{G}=$ putih telur $5 \%$.

Notasi a* menyatakan warna campuran merah dan hijau. Nilai a* dari 0 sampai 80 maka menyatakan warna merah dan nilai a* dari -80 sampai 0 menyatakan warna hijau. Bubuk tomat setiap perlakuan menghasilkan $a^{*}$ bernilai positif yaitu berkisar antara 17,31 sampai 25,73 dan dapat dikatakan ekstrak berwarna merah.

Notasi $b^{*}$ menyatakan warna campuran biru dan kuning. Nilai $b^{*}$ dari 0 sampai 70 maka menyatakan warna kuning dan nilai b* dari -70 sampai 0 menyatakan warna biru. Pada bubuk tomat setiap perlakuan menghasilkan $\mathrm{b}^{*}$ bernilai positif yaitu berkisar antara 19,00 sampai 26,40 dan dapat dikatakan bubuk tomat berwarna kuning.

Chroma/Saturation adalah derajat intensitas suatu warna untuk mendefinisikan kemurnian suatu warna, baik cenderung kotor (grayish) maupun cenderung dominan (murni). Semakin tinggi nilai chroma (C), intensitas warnanya semakin rendah. Berdasarkan hasil penelitian didapatkan nilai chroma 26,00 sampai 36,87 , dengan nilai $\mathrm{C}$ tertinggi terdapat pada bubuk tomat perlakuan kontrol putih telur 5\%. Nilai Hue mewakili panjang gelombang dari warna yang dominan. Nilai Hue didapatkan dari $a^{*}$ dan b*. Nilai Hue ini akan disesuaikan dengan daerah kisaran warna kromatisitas dan akan dihasilkan jenis warna bubuk tomat. Pada penelitian ini nilai Hue rata-rata berkisar antara 44,85 sampai 50,65 sehingga seluruh sampel bubuk tomat pada penelitian ini masuk dalam daerah kisaran warna kromatisitas merah.

\section{Kadar Air}

Salah satu parameter yang harus diperhatikan pada penentuan mutu suatu produk bahan hasil pertanian kering seperti bubuk tomat apel adalah kadar air. Rata-rata kadar air bubuk tomat dapat dilihat pada Gambar 3. 


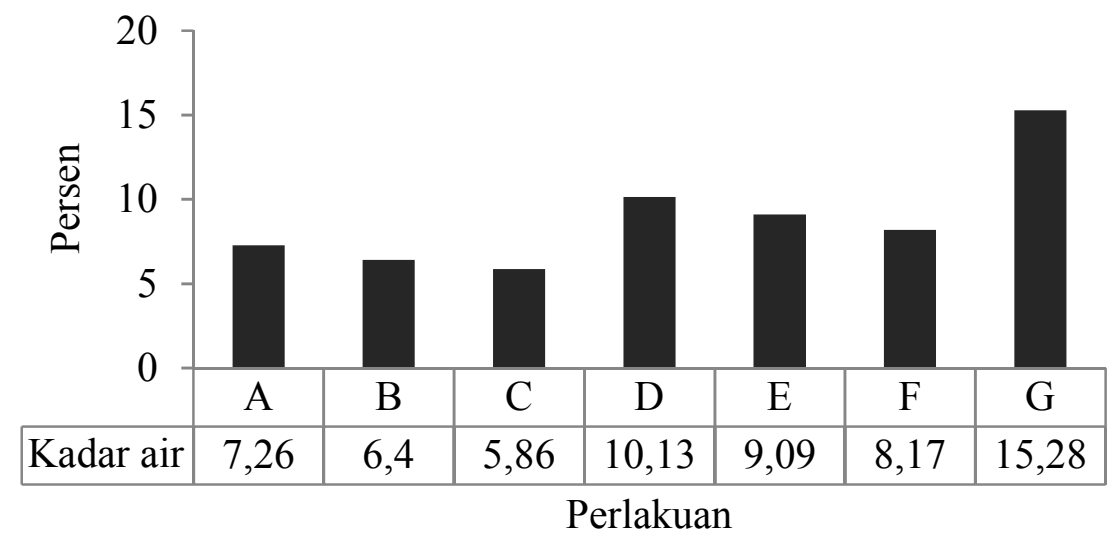

Gambar 3. Kadar air bubuk tomat. Keterangan: $\mathrm{A}=$ maltodekstrin $10 \%$, putih telur $5 \%$; $\mathrm{B}=$ maltodekstrin $15 \%$, putih telur $5 \%$; $\mathrm{C}=$ maltodekstrin $20 \%$, putih telur $5 \%$; $\mathrm{D}=$ maltodekstrin $10 \% ; \mathrm{E}=$ maltodekstrin $15 \% ; \mathrm{F}=$ maltodekstrin $20 \%$ dan $\mathrm{G}=$ putih telur 5\%.

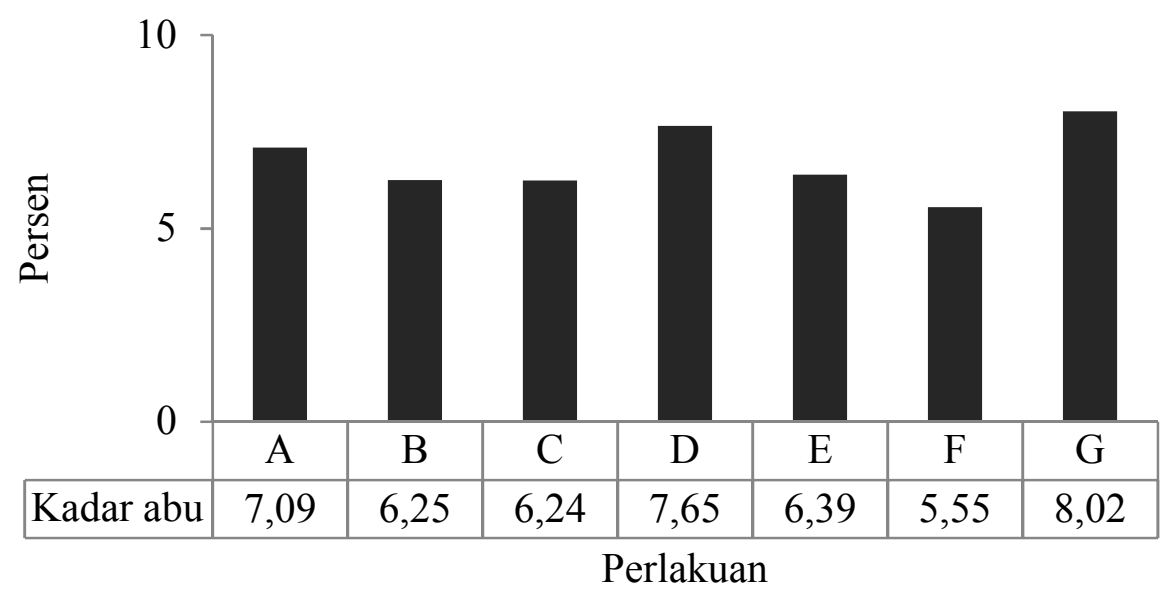

Gambar 4. Kadar abu bubuk tomat. Keterangan: $\mathrm{A}=$ maltodekstrin 10\%, putih telur 5\%; $\mathrm{B}=$ maltodekstrin $15 \%$, putih telur 5\%; $\mathrm{C}=$ maltodekstrin $20 \%$, putih telur $5 \%$; $\mathrm{D}=$ maltodekstrin 10\%; $\mathrm{E}=$ maltodekstrin $15 \% ; \mathrm{F}=$ maltodekstrin $20 \%$ dan $\mathrm{G}=$ putih telur 5\%.

Berdasarkan Gambar 3, kadar air bubuk tomat terendah adalah pada perlakuan $\mathrm{C}$ dengan nilai kadar air sebesar $5,86 \%$ basis basah. Kadar air bubuk tomat tertinggi adalah pada perlakuan $\mathrm{G}$ dengan nilai kadar air sebesar 15,28\% basis basah. Kadar air campuran jus dan pulp tomat berkisar antara 82,68\% higga 94,90\% menghasilkan lembaran kering tomat dengan kadar air berkisar antara 6,15\% hingga $16,02 \%$. Semakin tinggi kadar air campuran jus dan pulp tomat maka kadar air bubuk tomat juga semakin tinggi. Kadar air lembaran kering tomat dan kadar air bubuk tomat memiliki perbedaan, kadar air bubuk tomat lebih kecil dibanding dengan kadar air lembaran kering tomat. Hal ini diduga karena adanya proses penggilingan. Pada saat penggilingan, terjadi panas akibat adanya putaran pisau yang menggiling bahan sehingga bahan menjadi panas dan kadar air bubuk yang dihasilkan menjadi 
berkurang dari kadar air lembaran kering tomat. Konsentrasi maltodekstrin yang semakin tinggi akan mengikat air semakin besar sehingga kadar air akan semakin rendah (Ayu dkk., 2016). Penambahan maltodekstrin dapat meningkatkan total padatan pada bahan yang akan dikeringkan dan menurunkan kadar air produk (Phisut, 2012).

\section{Kadar Abu}

Abu adalah zat anorganik sisa hasil pembakaran suatu zat organik. Kandungan abu dan kompisisinya tergantung pada macam bahan dan cara penggabuaannya. Kadar abu berhubungan dengan mineral suatu bahan. Rata-rata kadar abu bubuk tomat tersaji pada Gambar 4.

Berdasarkan Gambar 4, kadar abu berkisar antara 5,55\% hingga 8,02\%. Kadar abu tertinggi adalah pada perlakuan $G$ dengan nilai kadar abu sebesar 8,02\% sedangkan kadar abu terendah adalah pada perlakuan $\mathrm{F}$ dengan nilai kadar abu sebesar $5,55 \%$. Semakin banyak maltodekstrin yang ditambahkan maka akan semakin menurun kadar abu bubuk tomat. Menurut (Ayu dkk., 2016), maltodekstrin tidak memiliki kandungan mineral bahan, sehingga penambahan maltodekstrin yang lebih sedikit justru membuat kandungan mineral total padatan produk menjadi lebih banyak dibanding penambahan maltodekstrin dalam jumlah yang lebih besar. Adanya pembusa yaitu putih telur pada perlakuan $\mathrm{A}, \mathrm{B}$, dan $\mathrm{C}$ menyebabkan peningkatan kadar abu. Hal ini dikarenakan putih telur mengandung 0,6\% kadar abu.

\section{Foam Density}

Foam density dapat menyatakan seberapa cepat pengeringan berlangsung. Semakin rendah nilai foam density maka pengeringan dapat berlangsun lebih cepat. Rata-rata foam density tersaji pada Tabel 2. Berdasarkan Tabel 2, nilai foam density berkisar antara $0,47 \mathrm{~g} / \mathrm{cm}^{3}$ hingga $1,02 \mathrm{~g} / \mathrm{cm}^{3}$. Nilai terendah adalah 0,47 $\mathrm{g} / \mathrm{cm}^{3}$ pada perlakuan A sedangkan nilai tertinggi adalah $1,02 \mathrm{~g} / \mathrm{cm}^{3}$ pada perlakuan F. Semakin banyak penambahan maltodekstrin maka besarnya nilai foam density akan semakin meningkat. Hal ini diduga karena dengan penambahan maltodekstrin terjadi kenaikan massa sehingga nilai foam densitynya akan semakin meningkat. Pada perlakuan D, E, dan $\mathrm{F}$ tanpa penambahan putih telur, nilai foam density lebih besar dibanding dengan perlakuan $\mathrm{A}, \mathrm{B}, \mathrm{C}$, dan $\mathrm{G}$ yang dengan penambahan putih telur. Hal tersebut diduga adanya penambahan putih telur meningkatkan busa yang dapat memperluas volume foam sehingga nilai foam densitynya lebih rendah dibanding nilai foam density perlakuan tanpa putih telur. Selain itu juga, massa foam perlakuan dengan penambahan putih telur lebih ringan dibanding dengan massa foam perlakuan tanpa penambahan putih telur. 


\begin{tabular}{lc}
\hline Perlakuan & Rata-rata $\left(\mathrm{g} / \mathrm{cm}^{3}\right) \pm \mathrm{SD}$ \\
\hline A (maltodekstrin 10\%, putih telur 5\%) & $0,47 \pm 0,01$ \\
B (maltodekstrin 15\%, putih telur 5\%) & $0,49 \pm 0,02$ \\
C (maltodekstrin 20\%, putih telur 5\%) & $0,57 \pm 0,01$ \\
D (maltodekstrin 10\%) & $0,97 \pm 0,01$ \\
E (maltodekstrin 15\%) & $1,01 \pm 0,02$ \\
F (maltodekstrin 20\%) & $1,02 \pm 0,03$ \\
G (putih telur 5\%) & $0,51 \pm 0,03$ \\
\hline
\end{tabular}

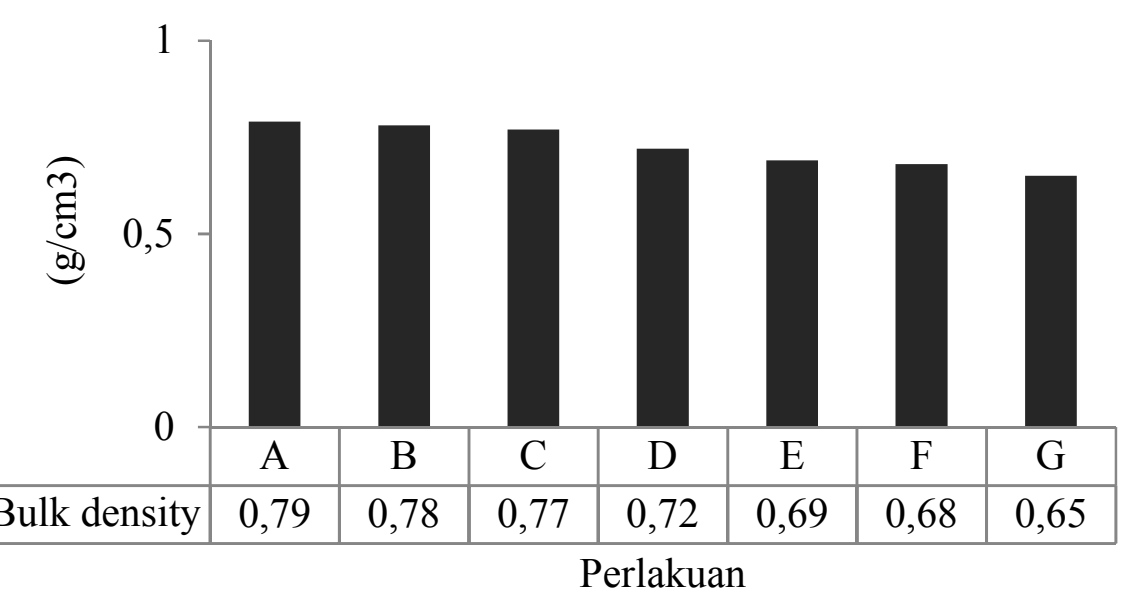

Gambar 5. Bulk density. Keterangan: $\mathrm{A}=$ maltodekstrin 10\%, putih telur 5\%; $\mathrm{B}=$ maltodekstrin $15 \%$, putih telur $5 \% ; \mathrm{C}=$ maltodekstrin $20 \%$, putih telur $5 \% ; \mathrm{D}=$ maltodekstrin $10 \% ; \mathrm{E}=$ maltodekstrin $15 \% ; \mathrm{F}=$ maltodekstrin $20 \%$ dan $\mathrm{G}=$ putih telur $5 \%$.

\section{Bulk Density}

Bulk

density

merupakan

perbandingan antara massa bubuk dengan

volume bubuk. Bulk density dalam industri biasanya dilakukan untuk membantu menentukan kapasitas bubuk dalam kemasan dan cara penyimpanan serta pendistribusiannya. Rata-rata bulk density tersaji pada Gambar 5.

Pada pengukuran bulk density, massa partikel yang terukur merupakan massa partikel dan massa rongga udara yang berada diantara dua partikel. Berdasarkan Gambar 5, nilai bulk density tertinggi adalah pada perlakuan A yaitu sebesar 0,79 $\mathrm{g} / \mathrm{cm}^{3}$ sedangkan nilai bulk density terendah adalah pada perlakuan $G$ dengan nilai sebesar $0,65 \mathrm{~g} / \mathrm{cm}^{3}$.

Semakin banyak maltodekstrin yang ditambahkan maka akan semakin menurun nilai bulk densitynya. Hal ini diduga karena semakin banyak maltodekstrin yang ditambahkan maka akan semakin kecil kadar air bubuk tomat yang dihasilkan sehingga massa bubuk tomat menjadi lebih kecil pada volume yang sama sehingga nilai bulk densitynya juga akan menjadi menurun. Kadar air yang rendah memiliki ukuran partikel yang kecil sehingga memiliki volume yang lebih rapat dan mengahasilkan nilai densitas kamba yang kecil (Widodo dkk., 2015). 


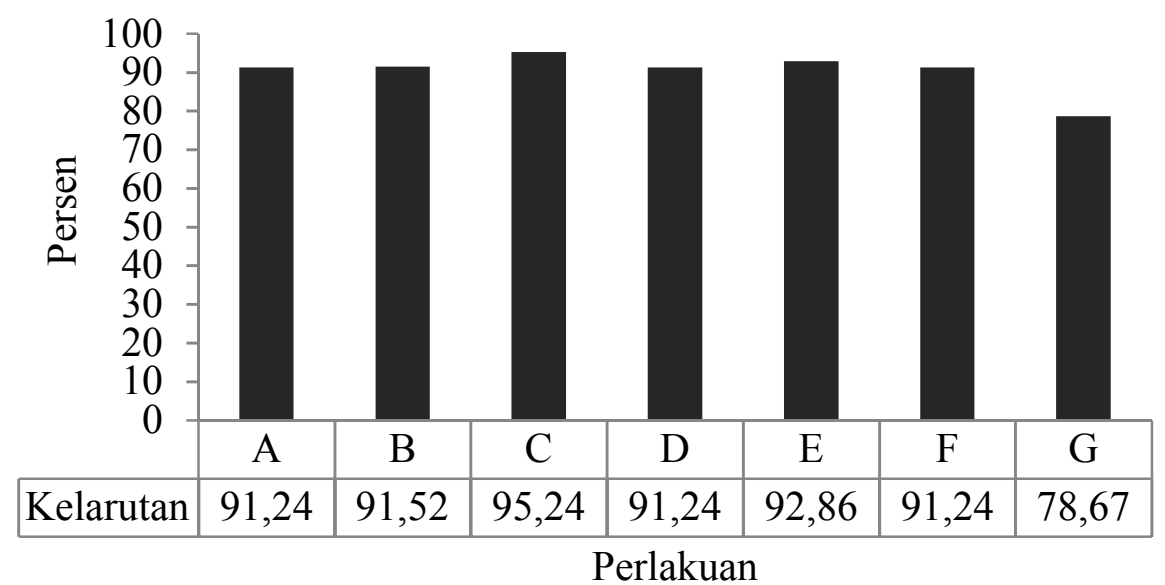

Gambar 6. Kelarutan bubuk tomat. Keterangan: $\mathrm{A}=$ maltodekstrin 10\%, putih telur 5\%; $\mathrm{B}=$ maltodekstrin $15 \%$, putih telur 5\%; $\mathrm{C}=$ maltodekstrin $20 \%$, putih telur $5 \%$; $\mathrm{D}=$ maltodekstrin $10 \% ; \mathrm{E}=$ maltodekstrin $15 \% ; \mathrm{F}=$ maltodekstrin $20 \%$ dan $\mathrm{G}=$ putih telur 5\%.

\section{Kelarutan}

Berdasarkan Gambar 6, kelarutan bubuk tomat berkisar antara 78,67\% hingga 95,24\%. Nilai kelarutan tertinggi adalah $95,24 \%$ pada perlakuan $\mathrm{C}$ dan nilai kelarutan terendah adalah $78,67 \%$ pada perlakuan G. Semakin banyak maltodekstrin yang ditambahkan maka akan semakin meningkat kelarutan bubuk tomat. Maltodekstrin mempunyai sifat yang mampu mengikat zat-zat yang bersifat hidrofobik, selain itu maltodekstrin merupakan oligosakarida yang sangat mudah larut dalam air, sehingga mampu membentuk sistem larutan yang terdispersi merata (Retnanengsih dan Intan, 2014). Kelarutan juga dipengaruhi oleh kadar air bahan. Peningkatan air dalam bahan dalam jumlah banyak akan menyebabkan terbentuknya gumpalan, akibatnya dibutuhkan waktu yang lama untuk memecah ikatan antar partikel sehingga kemampuan produk untuk larut menurun.

\section{Indeks Penyerapan Air}

Berdasarkan Gambar 7, rata-rata nilai indeks penyerapan air bubuk tomat adalah $10,27 \%$ hingga $13,01 \%$. Indeks penyerapan air tertinggi adalah pada bubuk tomat perlakuan F dengan nilai 13,01\% sedangkan indeks penyerapan air terendah adalah pada bubuk tomat perlakuan G dengan nilai $10,27 \%$. Konsentrasi maltodekstrin yang semakin tinggi akan mengikat air semakin besar sehingga kadar air akan semakin rendah. Menurut Phisut (2012), bahwa semakin rendah kadar air dalam suatu bahan maka daya serap air akan semakin besar.

\section{Higroskopisitas}

Tingkat higroskopisitas adalah kemampuan bahan untuk menyerap uap air dari lingkungan sekitar hingga bahan tidak 


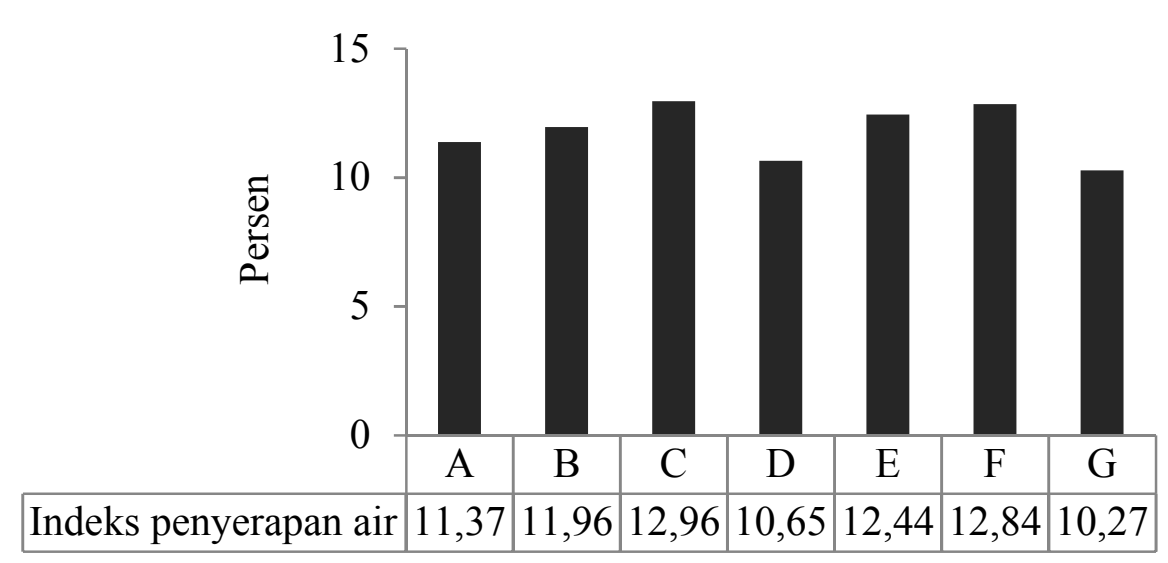

Perlakuan

Gambar 7. Indeks penyerapan air. Keterangan: $\mathrm{A}=$ maltodekstrin $10 \%$, putih telur $5 \%$; $\mathrm{B}=$ maltodekstrin $15 \%$, putih telur 5\%; $\mathrm{C}=$ maltodekstrin $20 \%$, putih telur $5 \%$; $\mathrm{D}=$ maltodekstrin $10 \% ; \mathrm{E}=$ maltodekstrin $15 \% ; \mathrm{F}=$ maltodekstrin $20 \%$ dan $\mathrm{G}=$ putih telur 5\%.

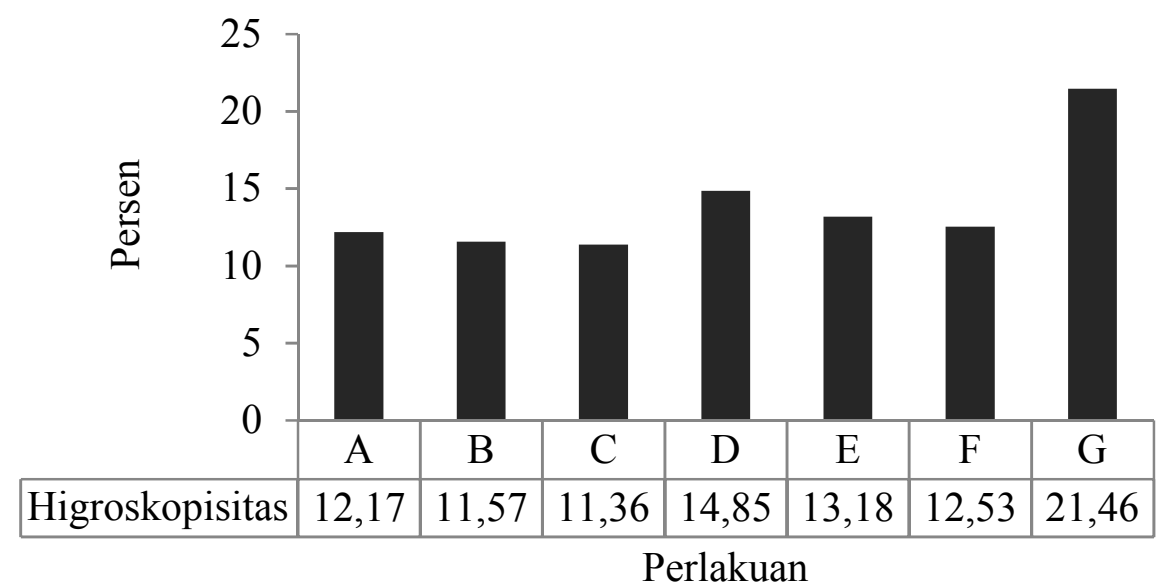

Gambar 8. Higroskopisitas. Keterangan: $\mathrm{A}=$ maltodekstrin $10 \%$, putih telur $5 \%$; $\mathrm{B}=$ maltodekstrin $15 \%$, putih telur $5 \% ; \mathrm{C}=$ maltodekstrin $20 \%$, putih telur $5 \%$; $\mathrm{D}=$ maltodekstrin $10 \% ; \mathrm{E}=$ maltodekstrin $15 \% ; \mathrm{F}=$ maltodekstrin $20 \%$ dan $\mathrm{G}=$ putih telur 5\%.

mampu lagi menyerap uap air. Berdasarkan

GEA Niro Research Laboratory (2005), bahan dengan tingkat higroskopisitas $<10 \%$ tergolong ke dalam bahan yang tidak higroskopis, $10,1-15 \%$ tergolong ke dalam bahan yang sedikit higroskopis, 15,1-20\% tergolong ke dalam bahan yang higroskopis, 20,1-25\% tergolong ke dalam bahan yang sangat higroskopis, dan $>25 \%$ bahan tergolong sangat higroskopis sekali.
Berdasarkan Gambar 8, rata-rata higroskopisitas bubuk tomat apel adalah 11,36\% hingga 21,46\%. Higroskopisitas tertinggi bubuk tomat apel pada perlakuan G dengan nilai 21,46\% dan higroskopisitas terendah bubuk tomat apel adalah pada perlakuan C dengan nilai 11,36\%. Semakin banyak maltodekstrin yang ditambahkan maka tingkat higroskopisitas bubuk tomat apel akan menurun. 


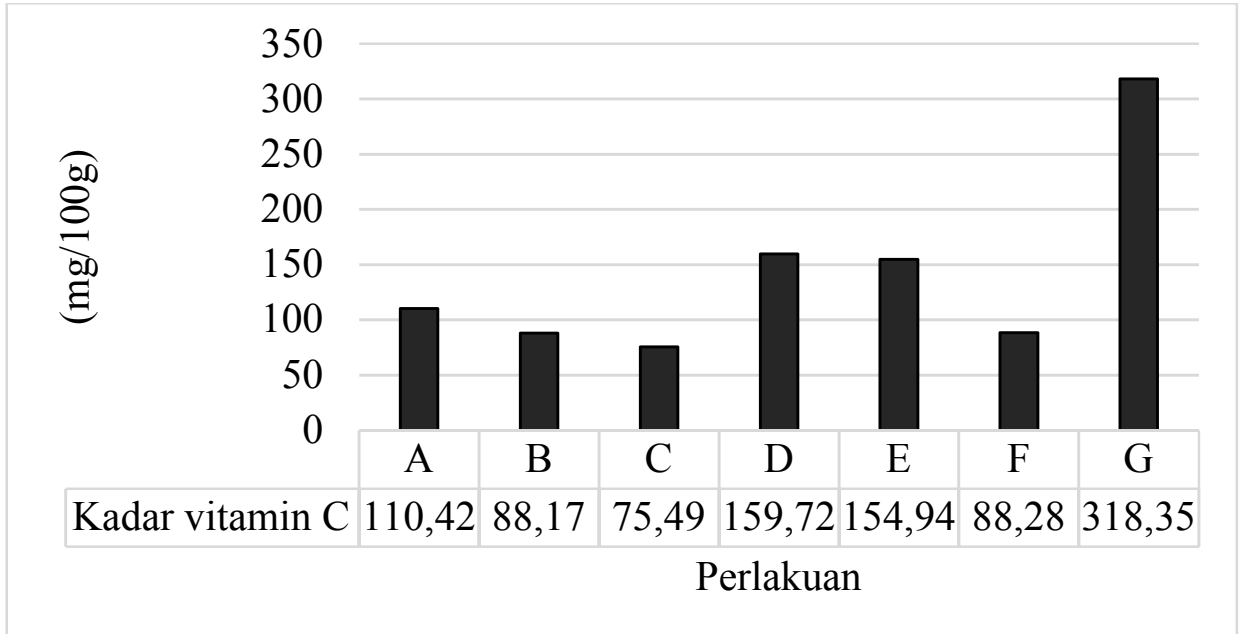

Gambar 9. Kadar vitamin $\mathrm{C}$ bubuk tomat. Keterangan: $\mathrm{A}=$ maltodekstrin $10 \%$, putih telur $5 \%$; $\mathrm{B}=$ maltodekstrin $15 \%$, putih telur $5 \% ; \mathrm{C}=$ maltodekstrin $20 \%$, putih telur $5 \%$; $=$ maltodekstrin $10 \% ; \mathrm{E}=$ maltodekstrin $15 \% ; \mathrm{F}=$ maltodekstrin $20 \%$ dan $\mathrm{G}=$ putih telur 5\%.

Penurunan tingkat higroskopisitas ini terjadi karena gugus hidrofob yang dimiliki oleh maltodekstrin menyebabkan sulitnya bahan menyerap air dari lingkungan sehingga produk yang dihasilkan memiliki tingkat higroskopisitas yang rendah (Rizaldi, 2012). Menurut Phisut (2012), konsentrasi maltodekstrin memberikan higroskopis serbuk yang berbeda. Konsentrasi maltodekstrin yang tinggi.

\section{Kadar Vitamin C}

Vitamin C adalah salah satu dari jenis vitamin yang bersifat larut dalam air dan berperan sebagai salah satu antioksidan. Vitamin C merupakan vitamin yang mudah rusak karena pengaruh panas selama pengeringan. Adanya penambahan maltodekstrin diduga dapat melindungi kandungan vitamin $\mathrm{C}$ tomat selama proses pengeringan. Rata-rata kadar vitamin C dapat dilihat pada Gambar 9.
Bubuk tomat yang sudah dikeringkan masih memiliki kadar vitamin $\mathrm{C}$ meskipun menurun dari kadar vitamin $\mathrm{C}$ tomat pada kondisi segar. Kandungan vitamin C menurun setelah sari buah tomat dibuat menjadi bubuk. Penurunan tersebut diduga akibat kerusakan vitamin $\mathrm{C}$ yang disebabkan oleh proses oksidasi. Kadar vitamin $\mathrm{C}$ bubuk tomat berkisar antara 75,49 g/100g hingga 284,5 g/100 g. Kadar vitamin $\mathrm{C}$ tertinggi adalah bubuk tomat pada perlakuan $\mathrm{G}$ dengan nilai $284,5 \mathrm{~g} / 100 \mathrm{~g}$ sedangkan kadar vitamin $\mathrm{C}$ terendah bubuk tomat adalah pada perlakuan $\mathrm{C}$ dengan kadar vitamin C sebesar 75,49 g/100g. Penambahan maltodekstrin diduga dapat menurunkan kadar vitamin C. Berdasarkan Retnanengsih dan Intan (2014) maltodekstrin mengandung oligosakarida, oligosakarida merupakan senyawa yang mempunyai gugus hidroksil $(\mathrm{OH})$ yang banyak sehingga mampu menetralisir sifat 
asam. Nilai kadar vitamin C pada perlakuan $\mathrm{A}, \mathrm{B}, \mathrm{C}$ lebih rendah dibandingkan dengan perlakuan D, E, F; hal ini diduga karena pada perlakuan A, B, C terjadi penambahan putih telur. Adanya putih telur dapat memperluas permukaan bahan yang dikeringkan sehingga kontak bahan dengan udara pengering semakin meningkat, hal ini menyebabkan penurunan kadar vitamin $\mathrm{C}$ pada perlakuan tersebut. Pada perlakuan G tidak ada penamabahan maltodekstrin sehingga sifat asam dari tomat tidak dinetralisir, dan vitamin $\mathrm{C}$ dilindungi oleh busa dari putih telur.

\section{KESIMPULAN}

1. Pembuatan bubuk tomat apel dengan menggunakan metode pengeringan pembusaan membutuhkan bahan pengisi maupun bahan pembusa guna mendapatkan hasil yang optimal.

2. Perbedaan penambahan maltodekstrin pada proses pengeringan pembusaan mempengaruhi rendemen total bubuk tomat apel, dengan nilai rendemen terbaik sebesar $15,29 \%$ dengan penambahan maltodekstrin sebesar 20\% dan putih telur $5 \%$.

3. Perbedaan penambahan maltodekstrin pada pengeringan pembusaan mempengaruhi karakteristik fisikokimia bubuk tomat apel dengan perlakuan penambahan maltodekstrin $20 \%$ dan putih telur 5\% memberikan hasil terbaik yaitu kadar air 5,86\% basis basah; kadar abu 6,24\%; kelarutan 95,24\%; indeks penyerapan air 12,96\%; tingkat higroskopisitas 11,36\%; kadar vitamin C $75,49 \mathrm{mg} / 100 \mathrm{~g}$, serta menghasilkan bubuk tomat dengan warna kromatis merah.

4. Perbedaan penambahan maltodekstrin berpengaruh terhadap laju pengeringan. Semakin banyak maltodekstrin yang ditambahkan maka laju pengeringan semakin menurun karena semakin besar total padatan dalam umpan yang dikeringkan maka semakin sedikit jumlah air yang harus dievaporasi.

\section{DAFTAR PUSTAKA}

Ayu, M., U. Rosidah, dan G. Priyanto. 2016. Pembuatan sambal cabai hijau instan dengan metode foam mat drying. Prosiding Seminar Nasional Lahan Suboptimal 20-21 Oktober 2016. Universitas Sriwijaya. Palembang.

Departemen Kesehatan Republik Indonesia. 1995. Daftar komposisi zat gizi pangan Indoneisa. Jakarta: Departemen Kesehatan.

Djaeni, M., M.S. Triyastuti, dan H.S. Rahardjo. 2016. Pengaruh pengeringan dengan metode gelembung terhadap sifat fisik produk ekstrak bunga rosela. Reaktor, 16(2): 96-102.

GEA Niro Research Laboratory. 2005. Higroscopicity GEA Niro Method No. A 14 a (on-line). https://www. gea.com/en/binaries/A $\% 2014 \% 20 \mathrm{a} \%$ 20-\%20Hygroscopicity tcm 11 - 
30922. pdf. (Diakses 3 Agustus 2017).

Hayati, R.H., R.A. Nugrahani, dan L. Satibi. 2015. Pengaruh konsentrasi maltodekstrin terhadap rendemen pada pembuatan santan kelapa bubuk (coconut milk powder). Prosiding Seminar Nasional Sains dan Teknologi 2015. Fakultas Teknik Universitas Muhammadiyah Jakarta, 17 November 2015, Jakarta.

Kamsiati, E. 2004. Pembuatan bubuk sari buah tomat (Lycopersicon esculentum Mill.) Dengan Metode "Foam-Mat Drying”. Jurnal Teknologi Pertanian, 7 (2): 113 - 119.

Mulyani, Yulistiani, dan Nopriyanti. 2014. Pembuatan bubuk sari buah markisa dengan metode "foam-mat drying". Jurnal Rekapangan, 8(1):22 - 38

Nurcholis, M., T. Dewanti, W.D. Rukmi, dan J.M. Maligan. 2010. Aneka produk olahan tomat dan cabe. Modul. Fakultas Teknologi Pertanian. Universitas Brawijaya. Malang.

Paramita, I., S. Mulyani, dan A. Hartiati. 2015. Pengaruh konsentrasi maltodekstrin dan suhu pengeringan terhadap karakteristik bubuk minuman sinom. Jurnal Rekayasa dan Manajemen Agroindustri, 3(2):56-68
Rajkumar, P., R. Kailapan, R. Viswanathan, and G.S.V. Raghavan. 2006. Drying dryer. Journal of Food Engineering, 79: 1452-1459.

Retnanengsih, N.A. dan N.T. Intan 2014. Analisis minuman instan secang: tinjauan proporsi putih telur, maltodekstrin, dan Kelayakan Usahanya. Jurnal Agrin, 18 (2): 129 147.

Rizaldi, A. 2012. Kajian Penggunaan maltodekstrin pada pembuatan gula aren serbuk dengan metode spray drying. Skripsi. Jurusan Teknologi Pangan, Fakultas Teknologi Industri Pertanian, Universitas Padjadjaran, Bandung.

Widodo, I. F., G. Priyanto, dan Hermanto. 2015. Karakteristik bubuk daun jeruk purut (Cytrus hystrix DC) dengan metode foam mat drying. Prosiding Seminar Nasional Lahan Suboptimal, Fakultas Pertanian Universitas Sriwijaya. 08-09 Oktober 2015 Palembang:

Xi'an. 2016. Tomat ekstrak, bubuk tomat alami lycopene bubuk 1\%-10\%. (online). http:www//id.naturalextractsob eo.com/standardextract/tomatoextract.html (Diakses 10 Mei 2017) 